原著

\title{
聴覚障害児における発話のピッチ・速度，音声強度の検討
}

\author{
広田栄子工藤多賀田中美 郷
}

\begin{abstract}
要 約 : 早期に補聴器を装用させて, ホームトレーニングプログラムを施行した中・高度聴覚障 害児 (36例) の発話を音響的に分析した. ついで, 聴覚印象によって音声障害の重症度を評価し, 聴カレベルの差異が音声障害の種類と程度に及ぼす影響を検討した。

その結果, (1)音声強度と強度の変動幅の増加を聴力70 dB 以上の群に認めた. (2)発話速度の低下 を聴力 $80 \mathrm{~dB}$ 以上の群に認め, 聴力 $100 \mathrm{~dB}$ 以上の群では一層の低下を認めた. (3)ピッチの変動幅 の減少は聴力 $90 \mathrm{~dB}$ 以上の群に認めたが, ピッチの平均値は正常児と差がなかった. さらに, 音声 障害の予後の推定の際には, 聴カレベルが $90 \mathrm{~dB}$ 以上であるか否かについて検討することの有用性 が示唆された。

本結果は, 聴覚障害児の音声障害の評価の際や，系統的な訓練を行う際の資料として利用できる.

索引用語 : 聴覚障害児, 音声障害, ピッチ, 強度, 発話の速度
\end{abstract}

\section{Voice Problems of Pitch, Loudness and Rate of Utterances in the Children with Hearing Losses}

\author{
Eiko Hirota, Taka Kudo and Yoshisato Tanaka
}

\begin{abstract}
The present experiment was undertaken to explore the relationship between voice problems and degree of hearing loss as well as the effect of the early auditory training in children with various degrees of hearing loss. A home training program was conducted on 36 hearing-impaired children from the early stage of childhood.

Their continuous monologues recorded on a magnetic tape were analyzed in terms of the peak levels of the fundamental frequency and the intensity as well as the rate of utterances by using a specially deviced pitch extractor. The results obtained were as follows: The deviation of pitch was noticeacably smallin children with severe hearing loss over $90 \mathrm{~dB}$ HL. Whereas the average level of pitch in these children was comparable with that obtained from normal subjects. The average level as well as the deviation of the intensity increased with the degree of hearing loss.

These results can be used for evaluations of the voice problems observed in hearingimpaired children and planning systematicl programs for their Speech therapy.
\end{abstract}

Key words : Hearing-impaired children, Voice problems, Pitch, Loudness, Rate of utterances

帝京大学耳鼻咽喉科学教室（主任：鉿木淳一教授）：空173 東京都板橋区加賀 $2-11-1$

Dept. of Otolaryngology, Teikyo University School of Medicine : 2-11-1, Kaga, Itabashi-ku, Tokyo-173, Japan 
はじめに

聴覚障害児の音声障害については，障害を惹起するお もな要因である聴カレベルの差異を考虑した評価法が有 用である.

聴覚障害児の音声の異常については, 音響分析機器の 開発以来, 多数の定量分析的な研究 ${ }^{1 \sim 4)}$ が 報告されてい る. しかし, 広範な聴力程度の難聴児を対象とし, 聴力 程度の差異と音声障害の程度および複数の障害の種類と の関係について，総合的に検討した報告は少なく，臨床 評価時の資料としては，不十分といえる．さらに，近年 では, 難聴の診断技術の進歩によって，早期に補聴と教 育を開始することが可能になり，臨床評価の基準には, このような症例による資料が必要になった。本研究は乳 幼児期に当科においてホームトレーニングを受け，早期 から訓練を開始した聴覚障害児を学齢時まで追跡しで, これらの症例の音声を分析し, 早期指導の成果を検討し たものである.

本研究の特徵は, (1)聴力 $50 \mathrm{~dB}$ から $120 \mathrm{~dB}$ までの広範 な聴力の感音性難聴児を対象とした. (2)音声のピッチ・ 強度・速度の障害について総合的に検討した（3)評価に は，音響的分析と聴覚印象による評価と両者を用いた， ことがあげられる。

本研究結果は臨床評価時の資料として利用できる。 さ らに, 本研究から教育や補聴によって改善しやすい音声 障害の種類や，改善の順序を知ることができ，本結果は 系統的な指導を行う際の資料として役立つと考える.

\section{対象と方法}

帝京大学耳鼻咽喉科ホームトレーニングプログラム ${ }^{5)}$ において, 難聴の診断と補聴器の適合を行い, 早期に教 育を開始した感音難聴児（ 7 ～10歳）36例を対象とし， 正常児（8歳） 6 例の結果と比較した. 表 1 に示すよう に, 難聴児を平均聴力レベルの程度によって，6 群（各 6 例）に分類し, 音声障害の種類と程度について群間で 比較した．各群における男女の割合は均等にした．各群 の被検児の教育開始年齢, 語音明瞭度（57語表）は表 1 のとおりである.

補聴器装用下の語音明瞭度検査では, 被検児をスピー カ前 $50 \mathrm{~cm}$ の位置に着席させ, 語音が被検児の快適音圧 レベルになるように補聴器の利得を調整させた。語音レ ベルは, 補聴器のマイクロホンの位置において57語表の 校正用純音が 75dB SPL になるようにスピーカの出力音 圧を調整した。

難聴児36例のらち，24例は現在普通小学校に在籍し， 12例は韵学校小学部に在籍していた. 就学前に当科で聴 能言語指導を行った症例は19例であり, 驡学校幼稚部で 教育を受けた症例は17例であった. 就学前には, 全例と も聴覚の活用を重視した言語指導をうけ，音声言語を習 得した.

音声材料には, 被検児の(1)自由な発話（夏休みについ て）と（2)文章の朗読（ジャックと豆の木）を用いた. 防音室内で, マイクロホン (SONY, ECM-23F) とテー プレューダ (SONY, TC-3000 SD) を用いて録音した. 被検児の自由な発話の基本周波数と音声強度の変化を, ピッチ抽出器 (Rion, SE-01) で抽出し, 高速グラフィッ

表 1 被検児の聴カレベルと教育開始年齢・語音明瞭度

\begin{tabular}{|c|c|c|c|c|c|c|c|c|}
\hline & $250 \mathrm{~Hz}$ & $500 \mathrm{~Hz}$ & $1,000 \mathrm{~Hz}$ & $2,000 \mathrm{~Hz}$ & $4,000 \mathrm{~Hz}$ & $8,000 \mathrm{~Hz}$ & 教育開始年齢 & 語音明瞭度 (\%) \\
\hline $\begin{array}{c}60 \mathrm{~dB} \text { 群 } \\
(50 \sim 69 \mathrm{~dB})\end{array}$ & $\begin{array}{c}43.3 \\
(9.9)\end{array}$ & $\begin{array}{c}50.8 \\
(6.1)\end{array}$ & $\begin{array}{c}59.2 \\
(8.4)\end{array}$ & $\begin{array}{c}68.3 \\
(14.9)\end{array}$ & $\begin{array}{c}79.2 \\
(22.4)\end{array}$ & $\begin{array}{c}81.7 \\
(12.1)\end{array}$ & $\begin{array}{c}3 \text { 歳 } 4.5 \text { 月 } \\
(12.2 \text { 月) }\end{array}$ & $\begin{array}{l}56.0 \\
(7.3)\end{array}$ \\
\hline $\begin{array}{c}70 \mathrm{~dB} \text { 群 } \\
(70 \sim 79 \mathrm{~dB})\end{array}$ & $\begin{array}{c}54.2 \\
(16.9)\end{array}$ & $\begin{array}{c}59.2 \\
(10.6)\end{array}$ & $\begin{array}{c}75.0 \\
(2.9)\end{array}$ & $\begin{array}{c}78.3 \\
(9.0)\end{array}$ & $\begin{array}{c}81.7 \\
(17.7)\end{array}$ & $\begin{array}{c}89.2 \\
(9.3)\end{array}$ & $\begin{array}{c}2 \text { 歳11.7月 } \\
\text { (12.6月) }\end{array}$ & $\begin{array}{c}49.3 \\
(11.8)\end{array}$ \\
\hline $\begin{array}{c}80 \mathrm{~dB} \text { 群 } \\
(80 \sim 89 \mathrm{~dB})\end{array}$ & $\begin{array}{c}63.3 \\
(14.9)\end{array}$ & $\begin{array}{c}74.2 \\
(8.9)\end{array}$ & $\begin{array}{c}88.3 \\
(3.9)\end{array}$ & $\begin{array}{c}98.3 \\
(9.0)\end{array}$ & $\begin{array}{c}95.8 \\
(12.7)\end{array}$ & $\begin{array}{c}98.3 \\
(17.2)\end{array}$ & $\begin{array}{c}1 \text { 歳 } 8.8 \text { 月 } \\
\text { ( } 6.0 \text { 月) }\end{array}$ & $\begin{array}{c}29.3 \\
(15.3)\end{array}$ \\
\hline $\begin{array}{c}90 \mathrm{~dB} \text { 群 } \\
(90 \sim 99 \mathrm{~dB})\end{array}$ & $\begin{array}{c}76.7 \\
(12.8)\end{array}$ & $\begin{array}{c}82.5 \\
(5.6)\end{array}$ & $\begin{array}{c}93.3 \\
(4.7)\end{array}$ & $\begin{array}{l}105.0 \\
(5.8)\end{array}$ & $\begin{array}{l}109.2 \\
(9.3)\end{array}$ & $\begin{array}{l}108.3 \\
(14.9)\end{array}$ & $\begin{array}{c}1 \text { 歳 } 9.5 \text { 月 } \\
\text { ( } 5.0 \text { 月) }\end{array}$ & $\begin{array}{c}13.0 \\
(9.7)\end{array}$ \\
\hline $\begin{array}{c}100 \mathrm{~dB} \text { 群 } \\
(100 \sim 109 \mathrm{~dB})\end{array}$ & $\begin{array}{c}83.3 \\
(9.0)\end{array}$ & $\begin{array}{c}90.0 \\
(8.2)\end{array}$ & $\begin{array}{l}106.7 \\
(6.2)\end{array}$ & $\begin{array}{l}116.7 \\
(8.0)\end{array}$ & $\begin{array}{l}116.7 \\
(12.8)\end{array}$ & $\begin{array}{l}110.8 \\
(9.3)\end{array}$ & $\begin{array}{c}1 \text { 歳 } 9 \text { 月 } \\
(9.5 \text { 月) }\end{array}$ & $\begin{array}{c}0.0 \\
(0.0)\end{array}$ \\
\hline $\begin{array}{c}110 \mathrm{~dB} \text { 群 } \\
(110 \sim 120 \mathrm{~dB})\end{array}$ & $\begin{array}{l}100.0 \\
(5.0)\end{array}$ & $\begin{array}{l}107.5 \\
(6.3)\end{array}$ & $\begin{array}{l}115.8 \\
(3.4)\end{array}$ & $\begin{array}{l}122.5 \\
(6.9)\end{array}$ & $\begin{array}{l}118.3 \\
(15.5)\end{array}$ & $\begin{array}{l}110.0 \\
(11.2)\end{array}$ & $\begin{array}{c}1 \text { 歳 } 1.3 \text { 月 } \\
(3.6 \text { 月) }\end{array}$ & $\begin{array}{c}0.0 \\
(0.0)\end{array}$ \\
\hline
\end{tabular}

聴力別の 6 群において, 各群の平均値と標準偏差（括孤内）を示した. 
クレコーダ(Rion, LR-51)で記録した $(3 \mathrm{~mm} / 100 \mathrm{msec})$. 録音した自由発話のなかで，連続的に発話を認めた 15 秒 間について，(1)音声のピッチ，(2)ピッチの変動幅，(3)音 声強度, (4)音声強度の变動幅, (5)発話の速度の 5 種の分 析を行った. 5 項目の分析方法は以下のとおりである.

音声のピッチ（話声位）としては，100msec ごとに基本 周波数の最大值を測定し，全区間の測定值の平均值を用 いた. 音声のピッチの变動幅には, 上記の方法で測定し た基本周波数の 1 標準偏差を用いた. 音声強度と強度の 変動幅については，ピッチと同様のサンプリングの方法 を用いて測定した.なお，ピッチの変動幅については, 各被検者の話声位で除した結果を用いて被検児間の比較
を行った。 また，個々の被検児についてピッチの平均值 々変動幅の関係を検討するために, 基本周波数の出現度 数を周波数別に累積し, 症例ごとに示した. 周波数ごと の基本周波数の出現度数を個々の症例のサンプル採取数 で除して, 被検者間の結果の比較を行った。被検者の発 話の速度としては, 音声材料の 1 モーラ区分あたりの持 続時間を用いた。

聴覚印象による音声障害の重症度評価には，録音した 2 種の音声材料 (各1 分間) をテープレコーダで再生 し，6名の言語治療士（臨床経験 3 年以上）がヘッドホ ンを通じて別々に聴取し，正常から最重度の 5 段階の総 合評価を行った、軽度群の評価基準としては， 5 種未満
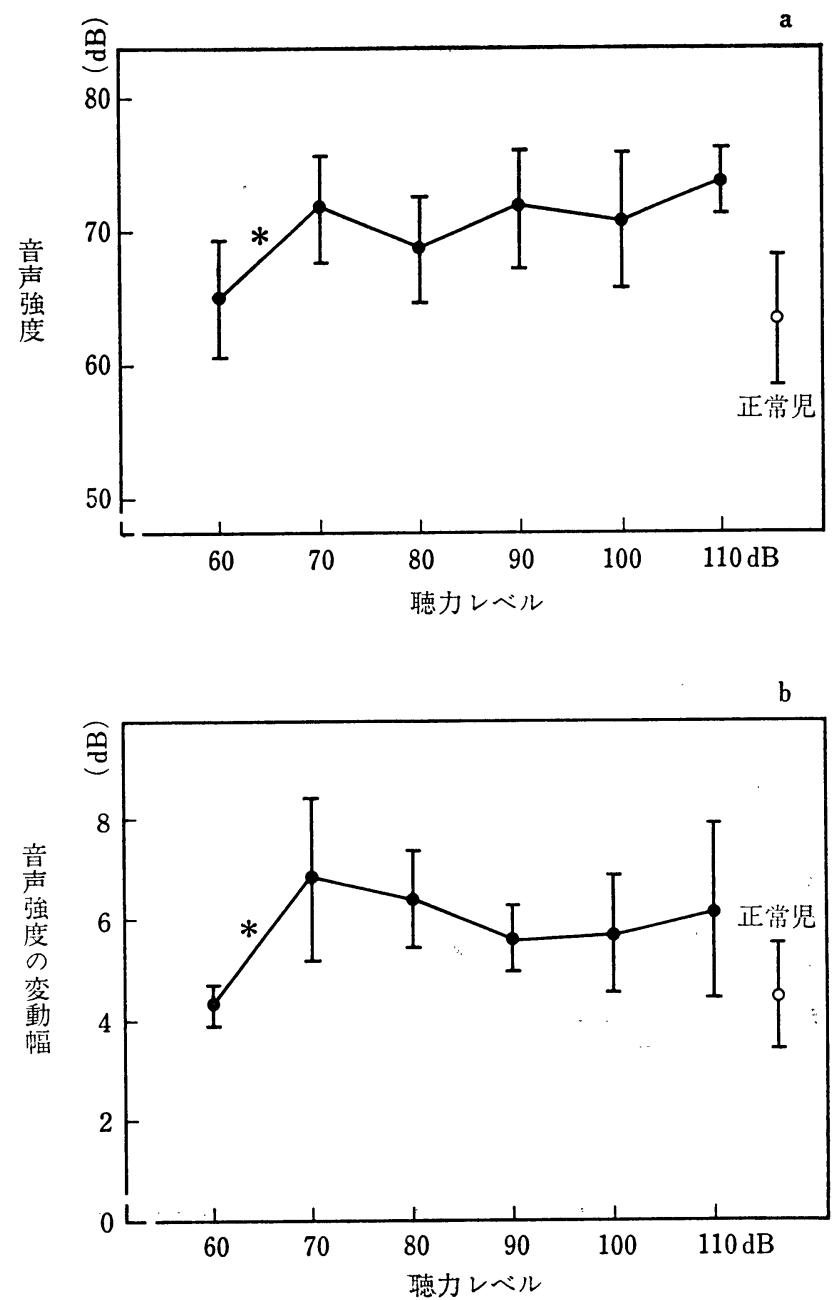

図 1 被検児の音声強度と聴力レベルとの関係 (図1-a). 被検児の音声 強度の変動幅と聴力レベルとの関係 (図1-b). 図では, 横軸に聴力 別の 6 群を示した. グラフは, 各群の平均值と標準誤差（縦棒）を 示した. 㱛接する群間で結果を比較し, 統計的有意差 $(0.1 \%$ 水準) を認めた時に*印をつけた. 
の構音障害を認め, 発話中にときどき, 了解が困難な単 語を認める. 親律的な異常はほとんど認めないものとし た. 中度群は, 5 種以上の構音障害を認め, 発話中にと きどき, 了解が困難な単語を認める. 発話の速度の調整 の異常を認め, 流暢性に欠ける. 重度群は, 著しい構音 障害があり，了解が困難なことばをしばしば認める。抑 揚の異常や声の高さの翻転を認め, 韻律的な障害は著し い. 最重度群は, 著しい構音障害があり, 文意の了解が しばしば困難になる．親律的な調整をほとんど認めない あのとした. 上記の評価の基準の設定にあたっては, 検 者が典型症例について討議した. さらに, 同症例の障害 音声をくりかえし聴取し, 検者の評価を一致させた、検 者 6 名が任意に 3 名 1 組になり, 検討材料をおのおのが 聴いて評価し， 3 名中 2 名以上が一致した評価段階を採 用した.な报，検者は快適音圧レベルに音声材料を再生 して聴取したので, 音声材料の音声強度については評価 をしていない.

音響的分析結果と, 被検者の各種要因との相関係数の 算出の際には, 各数值は全症例の平均値で除し, 基準化 して用いた。

\section{結果}

\section{1. 聴カレベルと音声障害の関係}

本研究では, 聴覚障害児の音声を音響的に分析し, 聴 カの要因が音声障害の程度と種類に及ぼす影響を検討し た. 以下に, 各分析項目ごとの結果を詳述する.
1）音声の強度: 図 $1 \mathbf{a}$ に, 被検児の音声強度を示 し, 図 $1 \mathbf{b}$ に, 音声強度の変動幅を示した. 聴力別の群 間で結果を比較すると, 聴力 $70 \mathrm{~dB}$ 群の音声強度は, 聴 力 $60 \mathrm{~dB}$ 群の結果と比べて増大し (6.7dB), 音声強度の 変動幅も同様に増大 (2.5dB) した. 差は統計的に有意 であった（強度 : $\mathrm{t}=3.34, \mathrm{df}=10, \mathrm{p}<0.01$, 変動幅 : $\mathrm{t}=2.99, \mathrm{df}=10, \mathrm{p}<0.01)$. 聴力 $60 \mathrm{~dB}$ 群に怙ける音声 強度と, 正常児の結果（平均63.5dB, $1 . \mathrm{S} . \mathrm{D}=4.88$ ) と を比べると差は少なく $(1.6 \mathrm{~dB})$, 差は統計的に有意では なかった. 音声強度の変動幅についても, 正常児の結果 （平均 $4.0 \mathrm{~dB}, 1$. S. D. = 1.0） と比べて差は少なく（0.3 $\mathrm{dB})$, 差は統計的に有意ではなかった. 正常児の音声強度 の変動幅の群内平均値 $(3.98 \mathrm{~dB})$ に対して 1 標準偏差 （1.0）の範囲 $(2.98 \sim 4.98 \mathrm{~dB})$ にあった 難聴症例数を 聴力別群間で比較すると, 聴力 $60 \mathrm{~dB}$ 群では 6 名中 5 名 が正常範囲であった. 一方, 聴力 $70 \mathrm{~dB}$ 群では 1 名, 80 $\mathrm{dB}$ 群 1 名, $90 \mathrm{~dB}$ 群 2 名, $100 \mathrm{~dB}$ 群 1 名, $110 \mathrm{~dB}$ 群 1 名であった. 聴力 $70 \mathrm{~dB}$ 以上の症例では, 正常範囲の音 声強度の变動幅を示した症例は少なく, それ以外の症例 では音声強度の変動幅の増大を認めた。 $70 \mathrm{~dB}$ より高度 な 5 群の音声強度について, 群間で結果を比較すると差 は少なかった $(0.1 \sim 3 \mathrm{~dB})$. また, 音声強度の変動幅の 群間の差は, 同様に少なかった $(0.4 \sim 1.2 \mathrm{~dB})$. 差は, いずれも統計的に有意ではなかった.

2) 発話の速度 : 図 2 に, 被検児の発話の速度( 1 モー ラ区分の持続時間)を示した. 聴カレベルが悪化する と, 発話の速度は低下した，すなわち，聴力別の群間で

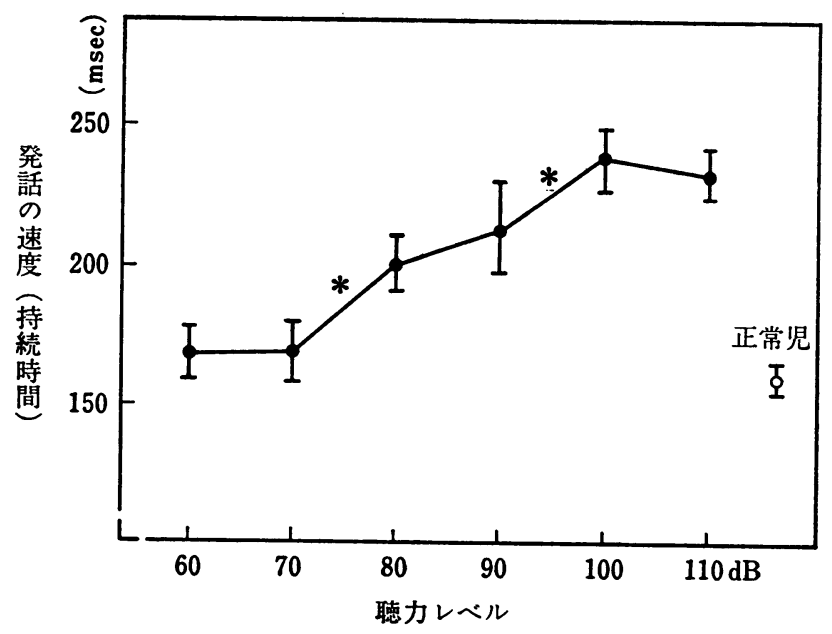

図 2 被検児の発話の速度（1 モーラ区分あたりの持続時間）と聴力レ ベルとの関係. 図では, 横軸に聴力別の 6 群を示した. 各群の平均 值と標準誤差 (縦棒) を示した. 隣接する群間で結果を比較し, 統 計的有意差 $(0.1 \%$ 水準) を認めた時に*印をつけた. 

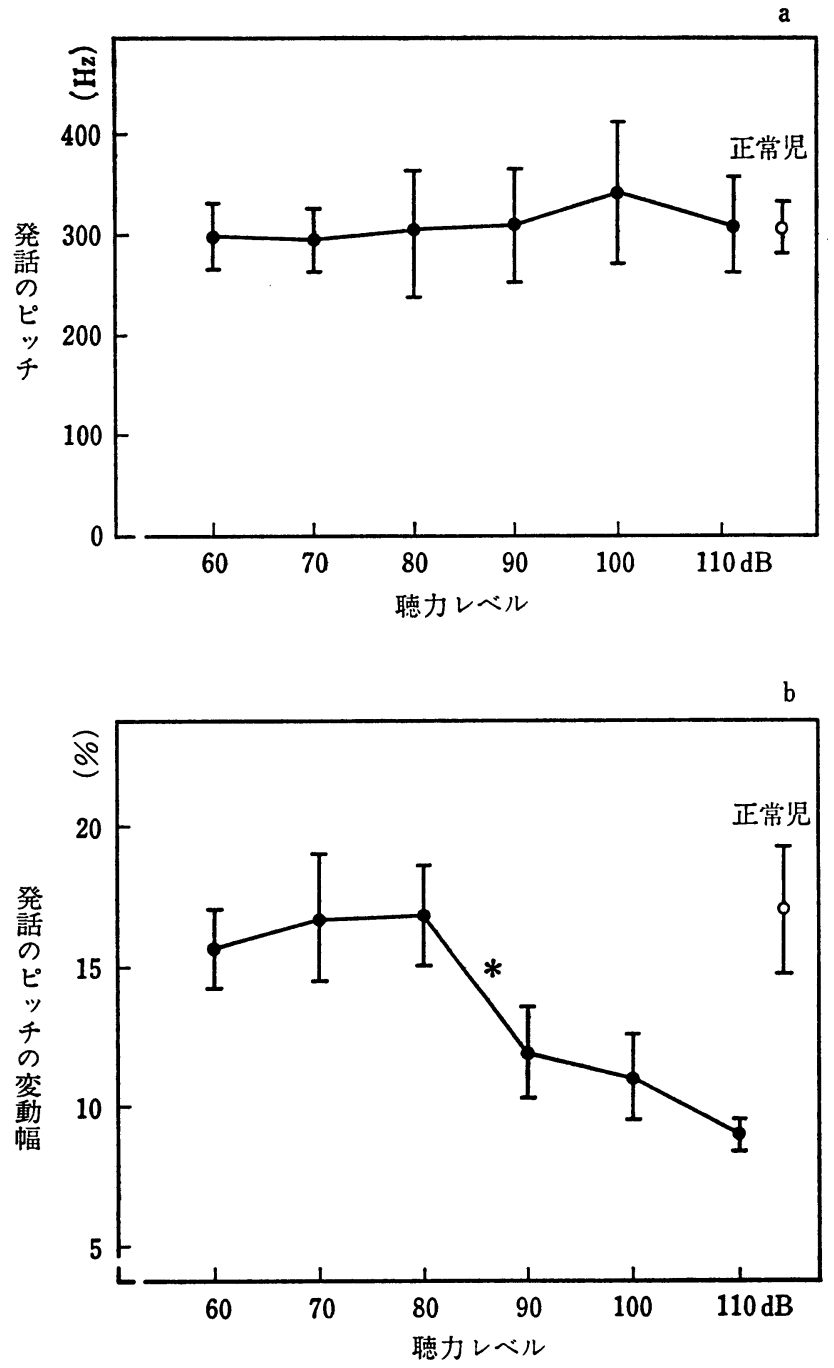

図 3 被検児の発語のピッチと聴力レベルとの関係 (図3-a). 被検児の 発話のピッチの変動幅と聴力レベルとの関係 (図3-b). 図では, 横 軸に聴力別の 6 群を示した. グラフは, 各群の平均值と 標準 誤 差 （縦棒）を示した. 隣接する群間で結果を比較し，統計的有意差 (0.1\%水準) を認めた時に $*$ 印をつけた.

結果を比較すると, 聴力 $80 \mathrm{~dB}$ 群の発話の持続時間は, $70 \mathrm{~dB}$ 群の結果と比べて延長し $(36 \mathrm{msec})$, 速度の低下は 統計的に有意であった $(\mathrm{t}=11.68, \mathrm{df}=10, \mathrm{p}<0.001)$. さらに, 聴力 $100 \mathrm{~dB}$ 群の発話の持続時間は, $90 \mathrm{~dB}$ 群と 比べて延長し $(30 \mathrm{msec})$, 一層の速度の低下を認めた $(\mathrm{t}=7.97, \mathrm{df}=10, \mathrm{p}<0.001)$. 聴力 $70 \mathrm{~dB}$ 群の発話の持 続時間と正常児の結果を比べると, 差は少なく差は統計 的に有意ではなかった.

3）発話のピッチ：図 $3 \mathrm{a} に$ に, 被検児の発話のピッチ （平均基本周波数）を示した. 聴力別の 6 群において,
群間の差は少なく（0.008〜0.083オクタープ), 聴力レ ベルの差異が発話のピッチに与える影響は認められなか った。 また, 難聴児の発話のピッチ（平均 $313.1 \mathrm{~Hz}$, 1.S. D. =56.1) と，正常児の結果(平均 $305.6 \mathrm{~Hz}, 1 . \mathrm{S} . \mathrm{D}$. =22.5）とを比べると差は小さく, 統計的有意差を認め なかった.

図 3 b に, 発話のピッチの変動幅を示した. 聴力別の 群間で結果を比較すると, 聴力 $90 \mathrm{~dB}$ 群のピッチの変動 幅は, 聴力 $80 \mathrm{~dB}$ 群の結果と比べて約 $5 \%$ 減少し, 差は 統計的に有意であった $(\mathrm{t}=3.21, \mathrm{df}=10, \mathrm{p}<0.01)$. す 
なわち, 聴力 $90 \mathrm{~dB}$ 群では, 声の抑揚は減少して発話は 単調になることが明らかになった. 聴力 $90 \mathrm{~dB}$ 群より聴 カレベルの高度な 3 群のピッチの変動幅を比較すると, 群間の差は少なかった $(0.8 \sim 2.9 \%)$. また, 聴力 $80 \mathrm{~dB}$ 群より聴カレベルの軽度な 3 群の群間の差も同様に少な かった $(0.11 \%)$. 差はいずれも統計的に有意ではなか った. 聴力 $60 \mathrm{~dB}$ 群におけるピッチの変動幅と, 正常児 の結果（平均 $16.5 \% ， 1$. S. D. $=5.5 ）$ と比べると差は少 なく，差は統計的に有意ではなかった。

図 4 亿, 聴力 $60 \mathrm{~dB}$ 群之 $70 \mathrm{~dB}$ 群の被検児 12 名（図 a ) および, 聴力 $100 \mathrm{~dB}$ 群と $110 \mathrm{~dB}$ 群の被検児 12 名 (困 b ) の個々の発話について, 基本周波数の累積相対度数（50 $\mathrm{Hz}$ ごと)を比較して示した. 1 本の折線グラフは 1 症例
の結果を示す. 図 4 では最頻度值を示した周波数は，被 検児の平均的ピッチ之视対応すると考えられる.グラ フの尖度の增加は, ピシチの変動幅の減少と対応すると 考兄られる. 両図 $(\mathrm{a}, \mathrm{b})$ を比較すると，平均的ピッチは 両群で差は少ない，また, 聴力 $100 \mathrm{~dB}$ 群・110dB 群の症 例では, 聴力 $60 \mathrm{~dB}$ 群・70dB 群の症例と比べてグラフの 尖度はいずれも高く，ピッチの变動幅の減少が顕著でピ ッチの障害としては，抑揚の平坦化を認めたといえる.

以上の結果をまとめると, (1)音声強度と強度の変動幅 の障害は, 聴力 $70 \mathrm{~dB}$ 群以上飞認め, (2)発話速度の障害 は, 聴力 $80 \mathrm{~dB}$ 群以上に認めた. (3)ピッチの変動幅の障 害は, 聴力 $90 \mathrm{~dB}$ 群以上に認め, さらに, (4)発話速度の 障害を, 聴力 $100 \mathrm{~dB}$ 群以上に認めた。
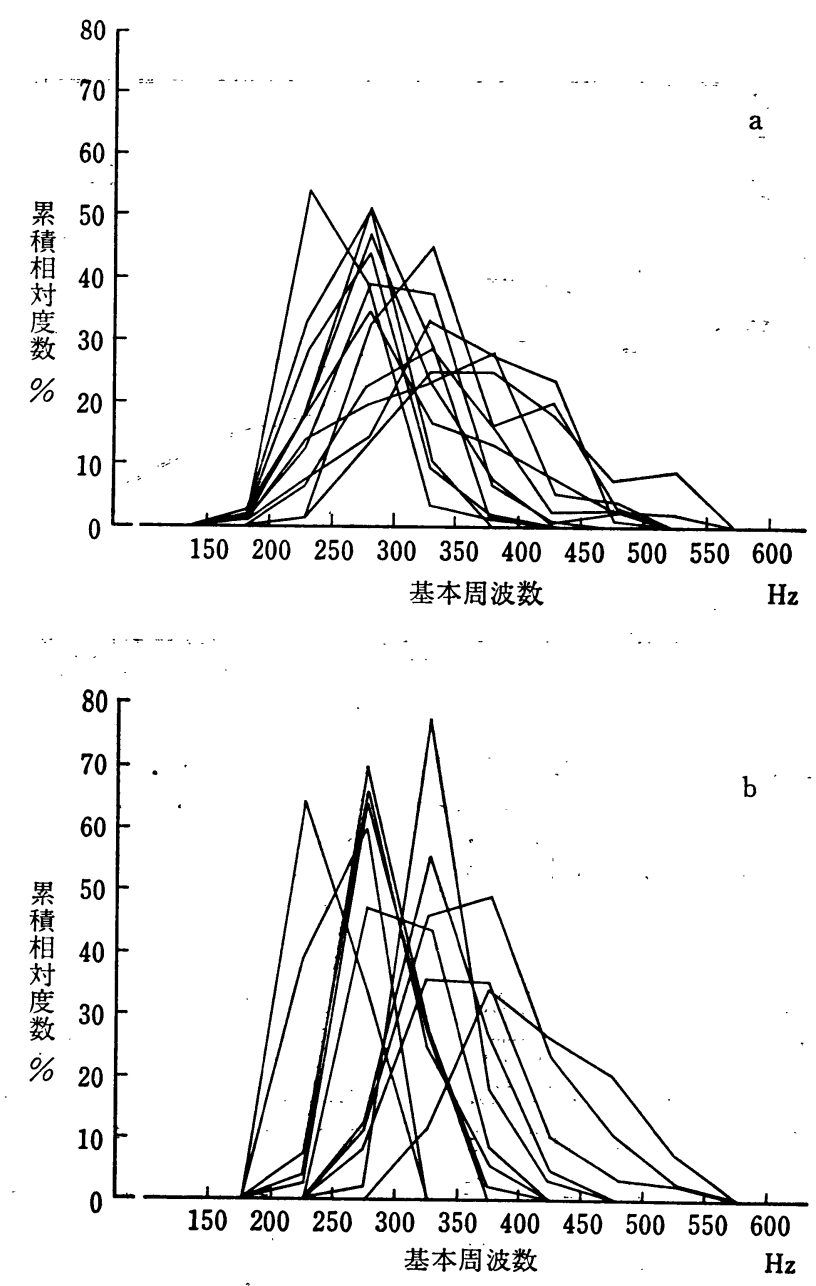

図 4 個々の被検児の発話における 基本周波数の累積相対度数. 上図 (a) には, 聴力 $60 \mathrm{~dB}$ 群と $70 \mathrm{~dB}$ 群の症例の分析結果を示し, 下図 (b) には, 聴力 $100 \mathrm{~dB}$ 群と $110 \mathrm{~dB}$ 群の症例の分析結果を示した. ひ とつの折線グラフは 1 症例の結果を示した: 


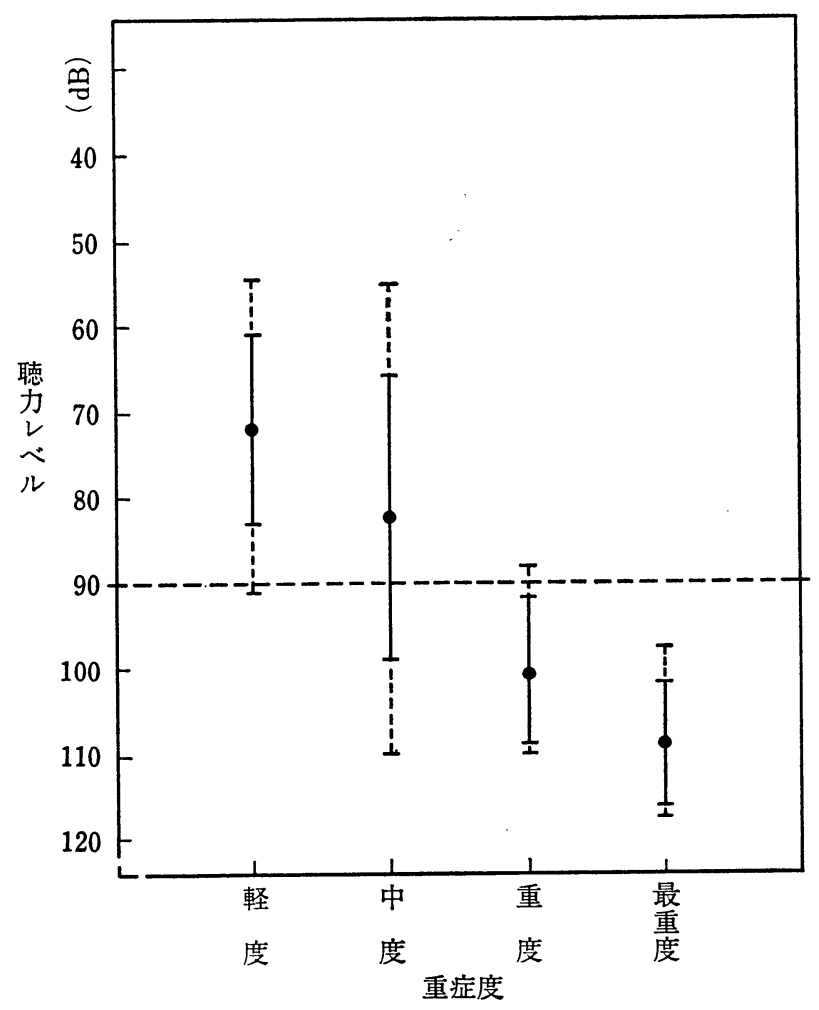

図 5 被検児の聴カレベルと聴覚印象による音声障害の重症度との関 係. 横軸に, 音声障害の重症度別の 4 群を示し, 各群の症例の平均 聴力レベルの群内平均值と標準偏差 (縦棒実線) とレンジ（縦棒点 線)を示した.

\section{2. 音声障害の重症度と聴カレベルとの関係}

音声障害の重症度を聴覚印象によって総合的に評価し て被検児を分類し, 各群の被検児の聴力程度を検討し た. 重症度評価の結果, 正常：0名, 軽度 : 12 名, 中度 : 7 名, 重度 : 9 名, 最重度：8名に被検児を分類し, 群 間で聴力程度を比較した（図 5 ).

音声障害が重度になると, 聴力レベルは悪化した.す なわち, 音声障害の重症度中度群の聴力レベルは, 軽度 群より高く $(\mathrm{t}=1.49, \mathrm{df}=17, \mathrm{p}<0.01)$. 重度群の聴力 は, 中度群より高かった $(\mathrm{t}=2.78, \mathrm{df}=14, \mathrm{p}<0.001)$. 最重度群の聴力は, 重度群より高 $<（ \mathrm{t}=2.07, \mathrm{df}=15$, $\mathrm{p}<0.0012$, 被検児の聴力程度の要因が音声の 重症度に 及ぼす影響は大きいことを確認できた.つぎに, 被検児の 聴力の分布に注目すると, 重度群と最重度群の被検児の 聴力のばらつきは小さく, $90 \mathrm{~dB} よ り$ 高值に17例中 15 例 の分布を認め, 残り 2 名の聴力はそれぞれ $89 \mathrm{~dB}, 87 \mathrm{~dB}$ であった. 一方, 軽度群の症例では, $90 \mathrm{~dB}$ より低值に

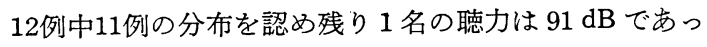
た. 中度群では聴力の分布は広範で個人差が著しいこと
がわかった.

\section{3. 音声障害と関連する要因の検討}

表 2 に今回の分析結果と被検児の各種要因 (平均聴力 レベル, 語音明瞭度, 生活年齢, 読書力検査結果, 教育 開始年齢, 発語明瞭度) との相関係数を示した.今回 は，早期に難聴と診断し，ホームトレーニングプログラ

表 2 音声障害と関連する要因の検討

\begin{tabular}{|c|c|c|c|c|c|}
\hline & $\begin{array}{l}\text { 発話の } \\
\text { ピッチ }\end{array}$ & $\begin{array}{l}\text { ピッチの } \\
\text { 変 動 幅 }\end{array}$ & 音声強度 & $\begin{array}{l}\text { 音声強度 } \\
\text { の変動幅 }\end{array}$ & 発話速度 \\
\hline 平均 & 107 & $-0.589 *$ & 0.445 & 0.125 & $0.556^{*}$ \\
\hline 語音明瞭度 & -0.141 & $0.715^{*}$ & -0.209 & 0.088 & $-0.557^{*}$ \\
\hline 生 活 年 齢 & - & 0.190 & -0.492 & -0.235 & -0.444 \\
\hline 読書力検査 & 0.0 & 0.02 & 0.125 & 0.005 & 0.012 \\
\hline 教育 & -0.046 & 0.385 & -0.298 & $8-0.096$ & -0.477 \\
\hline 発誙 & -0.151 & $0.559 *$ & -0.350 & 0.077 & $-0.560^{*}$ \\
\hline
\end{tabular}

今回の分析結果と, 被検児の各種要因との相関係数を算出 し, 統計的に有意 $(0.1 \%$ 水準, $\mathrm{df}=34)$ な相関を示した係数 に*印をつけた。 
ムを開始した症例を対象とした. 難聴診断時の被検児の 年㱓は, $80 \mathrm{~dB}$ より高度の症例では 2 歳 6 カ月以前, 70 $\mathrm{dB}$ 群では 3 歳以前, $60 \mathrm{~dB}$ 群では 4 歳 6 カ月以前の症例 を対象とした. 今回の諸検査を施行した時の被検児の年 齢は, 7 歳から10歳までとし, 幼児期から学童期の音声 の発達的変化および思春期の発達的要因の影響が少なく なるようにした，また，全例とも精神発達は正常であっ たが，言語の習得レベルの個人差の要因（読書力検査）

も検討した. 教育開始年龄, 生活年蹹, 言語習得レベル の要因については, 上記の範囲内での被検児の個人差 が, 本研究結果に与えた影響の有無について検討を加え た. その結果, ピッチの変動幅と発話速度は, 被検児の 聴力と語音明瞭度と発語明瞭度の 3 要因とそれぞれ相関 が高く, 係数は統計的に有意であった $(\mathrm{p}<0.001, \mathrm{df}=$ 34). 同分析結果と, 被検児の生活年龄, 読書力検 查 結 果, 教育開始年旍の各要因との相関係数は低值で, 統計 的に有意 $(\mathrm{p}<0.001)$ ではなかった. また, 発話のピッ チ, 音声強度, 音声強度の変動幅と被検児の各種要因と の相関係数は低値で, 統計的に有意 $(\mathrm{p}<0.001)$ ではな かった. すなわち, 聴覚障害児の主な音声の障害であっ たピッチの変動幅と発話速度は, 聴力や語音明瞭度など 聴覚系の障害の要因との関連性が著しく高いことを確認 できた。また，発語明瞭度の障害との関連性も著しく高 いことがわかった。

\section{考察}

音声言語には，音素や音節などに認められる特徴（分 節的特徵）と，連続した発話区分にわたって認められる 特徵 (韻律的特徽) とがある. 話者は, 発話のピッチや 強度, 速度の変化などにおける韻律的特徵によって, ア クセントや強調, イントネーション, 休止などを表現す る. また, 話者は発話の韻律的特徵によって語彙や構文 などの言語的情報を聞き手に伝達できる，さらに，話者 の個性や感情などの非言語的情報を伀達できる.

さきに，工藤ら ${ }^{19)} は ，$ 聴覚障害児の音声における分節 的側面の障害について検討し, 障害の程度は聴カレベル との関連性が高いと報告した。本研究では，聴覚障害児 の発話を音響的に分析したうえで, 韻律的側面の障害に ついて検討し, 分節的側面と同様に, 障害の程度は聴力 レベルとの関連性が高いことを明らかにした．以下に, 本研究結果と従来の研究結果とを比較し, 重要な項目に ついて考察を加えたい.

\section{1. 聴觉障害児の音声障害の種類}

1) 発話のピッチ

従来の研究では, 聴覚障害児の発話のピッチにおい
て，(1)話声位 ${ }^{7)}$ と(2)抑揚 7) の異常について報告されてい る.

話声位の障害については, 補聴による聴覚の補償が不 十分な時代の研究において, 聴覚障害の話声位は正常児 より高く，時にはうら声 (folset voice) を用いるといっ た報告 ${ }^{8,9,13)}$ がある. 近年では, 正常児の話声位と聴覚障 害児の話声位との間には, 差がないという Meckfessel ${ }^{10)}$ および Ermovick ${ }^{11)}$ の報告があるが，発達的な変化につ いては障害を認めたといら報告 ${ }^{10)}$ もある，すなわち，変 声期以前 ( 7 8 歳)の聴覚障害児では, 男子 $(292 \mathrm{~Hz})^{10)}$, 女子 $(235 \mathrm{~Hz})^{11)}$ とも, 正常児 (男子 : $289 \mathrm{~Hz}^{10)}$, 女子 : $245 \mathrm{~Hz})^{11}$ の話声位との差が少ない. 変声期以降（17〜18 歳) の聴覚障害児では, 男子 $(184 \mathrm{~Hz})$ は, 正常児 (130 $\mathrm{Hz})^{10)}$ より高値を示した. 女子 $(256 \mathrm{~Hz})^{11)}$ は，正常児 $(230 \mathrm{~Hz})$ よりわずかに高いが，個人差が大きく ${ }^{8,11)}$, 正 常児との差は男子ほど明らかではないと報告されてい る. 本研究では $7 \sim 10$ 歳の変声期以前の症例を対象と し, 話声位は正常児の值と差が少ないといら結果を得 た.この結果は, Meckfessel ${ }^{10)}$ や Ermovick ${ }^{11)}$ の報告 と一致していた.

聴覚障害児の抑揚について，従来の報告では，(1)ピッ チの変動の減少による発話の単調さ ${ }^{7,12)}$ と, (2) ピッチの 過剰な変動による異常7,12) が指摘されている. 適切なピ ッチの変化は, 特定の文意の強調や, 文末の疑問文と平 叙文の区別や, 構文の構造についての情報を伝達する.

本結果から, 今回の早期に教育を開始した聴覚障害児 のピッチの障害としては, ピッチの変動幅の減少が著し く, 抑揚の平坦化を認めたといえる. 本研究では, 正常 児 6 名の発話中のピッチの変動幅は0.65オクターブから 1.73オクターブ (平均1.02) の範囲にあった. 一方, 聴 覚障害児でピッチの変動幅の障害を多数認めた $90 \mathrm{~dB}$ 以 上の症例18名のうち, 上記の正常児の結果より変動幅の 少ない症例は, 13名 (72.7\%) 認めた. 反対に, 正常児 の結果より変動幅の大きい被検児は認められず, 本研究 における聴覚障害児のピッチの障害としては, 抑揚の平 坦化が著しいことが明らかになった。

抑揚の変化の範囲を超えた変動や，爆発的な変動は初 期の研究にしばしば報告されたが, 韻律的な情報の伝達 を妨げることになる. 聴覚障害児のピッチの過㮃な変動 の機序としては, (1)発声に関連する筋の過度な緊張と, 弛緩によって声の高さを調整しょうとする ${ }^{i, 13)}$. (2)異な る母音の産生に必要なフォルマント周波数の差を基本周 波数の差によって産生しようとする ${ }^{1)}$ といった解釈があ る. 本研究では, 正常児の範囲をこえた抑揚の変動を示 した聴覚障害児例を認めなかったが, 特定の母音の産生 時に基本周波数を変化させている症例を認め上記後者の 
機序を一部支持できる．本症例は聴力レベル110dB の聾 児であるが，母音「い」段において一貫してピッチの上 昇を認めた。

2) 発話の速度

聴覚障害児の発話の速度について, 従来の報告では, (1)発話速度が遅く ${ }^{1,14 \sim 16)}$ ，その結果，(2)発話の明瞭性を 著しく低下させている ${ }^{1,7,14)}$ という点について,一致した 見解を示している. 以下に聴覚障害者の発話速度（括弧 内 : 前部) と正常者の発話速度 (括弧内: 後部) とを比 較した従来の研究結果を概括し，本研究で得た結果につ いて考察を加えた. すなわち, (1)1962, Tato $ら^{17)}(0.47$ sec : $0.27 \mathrm{sec} /$ syllable)), (2)1968, Calton $5^{15)}(8 \sim 10$ sec : 3 4 sec/sentence), (3)1974, 鏡 ${ }^{4)}$ ( $2 \sim 5 \mathrm{sec}$ : 1.5〜2 sec/おはようございます), (4)1976, Flecher ら ${ }^{16)}$ (173 words : 95 words $/ \mathrm{min}$.) などの報告がある. 著者ら の研究では, $80 〜 89 \mathrm{~dB}$ の聴覚障害児において $0.20 \mathrm{sec} /$ モーラ, $100 \mathrm{~dB}$ 以上の聴覚障害児において $0.24 \mathrm{sec} / モ ー$

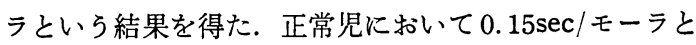
いら結果を得た．各報告の結果を比較するために，正常 児に対する速度の比を用いると，Tato ${ }^{17)}$, Calton $^{15)}$, 鏡 ${ }^{4)}$ らの報告では聴覚障害者の発話は正常者の発話の 2 倍以 上の速度の低下（持続時間の延長）を認めた．著者らの 研究では，障害は軽減し正常児との差は少なかった。す なわち, $80 \sim 89 \mathrm{~dB}$ 群の発話速度は正常児の 1.3 倍, 100 $\mathrm{dB}$ 以上の群は正常児の1.6倍であった．著者らの研究に おける $100 \mathrm{~dB}$ 以上の重度聴覚障害児の結果が近年の Flecher $ら^{16)}$ の結果 (1.8倍) に近似していた．聴覚障害児 の発話の速度の低下の機序としては，(1)語のストレスを 弁別する能力の低下によって，ストレスに伴ら音節の持 続時間の調整が困難である ${ }^{18)}$. (2)聴覚障害児が音節の正 確な構音に注目するために発話中の音節間に休止が入 $ろ^{8,14)}$. (3)発話に要する呼気の調整が不適切なために,

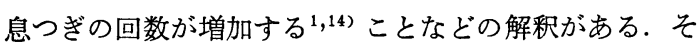
の結果, 聴覚障害児の発話では, 摩擦音の子音部の持続 時間や，破裂音の呼気閉鎖時間や，母音の持続時間が有 意に延長していたこと婑などが報告されているが，機序 については不明な点が多い.

\section{2. 聴觉障富児の音声障客と聴力との関係}

本研究では, 聴覚障害児の音声障害について聴覚印象 によって障害程度を評価し，障害程度別の群の症例の聴 カレベルを検討した．そして，軽度の音声障害を聴力 $90 \mathrm{~dB}$ 未満の症例に認め, 重度・最重度の 音声障害を聴 力 $90 \mathrm{~dB}$ 以上の症例に認めたことから, 音声障害の予後 の推定の際には，聴覚障害児の聴力が $90 \mathrm{~dB}$ 以上である か否かについて考慮することの有用性が示唆された. 聴 カレベルが $80 \mathrm{~dB}$ 以上と高度であったにもかかわらず,
軽度・中度の音声障害を示した症例（ 7 例）に共通した 特徽の検討は，同様に予後の推定の際の資料として利用 できる. 7 症例中, 6 症例の平均聴カレベルは $85 \mathrm{~dB}$ か ら $95 \mathrm{~dB}$ の範囲にあり，1症例は $110 \mathrm{~dB}$ であった．上記 6 症例に共通した特徵について同様の平均聴力 (80dB〜 $99 \mathrm{~dB})$ の他の症例と比較すると以下のとおりである.

音声障害の軽微な 6 症例では，(1)低周波数帯の残聴が 著しい（ $250 \mathrm{~Hz}$ の閾值が $65 \mathrm{~dB}$ 以内）聴力型を示した(他 症例の $250 \mathrm{~Hz}$ の閾值の平均 : $83 \mathrm{~dB}$ ). 本症例では 2,000 $\mathrm{Hz}$ の閾值は $110 \mathrm{~dB}$ 以内で高周波数帯の残聴も認めたが, 残聴の程度は他症例 $(2,000 \mathrm{~Hz}$ の閾値の 平均 : $101 \mathrm{~dB})$ と差はない。(2)語音弁別能は20\%より良好であった（他 症例の平均: $12 \%$ ). (3)発語明瞭度は $60 \%$ より良好であ った（他症例の平均：38\%）などの特徴を示した．音声 障害が軽微であった上記 7 症例については，年龄や読書 力検査結果などに一定の傾向は認められず, 補聴器装用 開始の時期についても同様であった．本症例では，いず れも就学前に聴覚系の活用を重視した言語指導を行い音 声言語を習得させ，手指法は用いていない， 7 症例中 5 症例については当科で指導を行い, 1 症例は龍学校幼稚 部，他の 1 症例は難聴児通園施設にて指導をうけた， 7 症例は全例普通小学校に就学した.

\section{3. 聴覚障害児の音声における分節的障害と䇎律的障}

\section{害}

聴覚障害児の音声の臨床的評価には，韻律的障害と分 節的障害の両側面の検討を欠かせない，早期に教育を開 始した聴覚障害児において，両側面の障害の程度はいず れも聴力程度との関連性が高いことが本研究および工藤 ら ${ }^{19)}$ の研究によって明らかになった．分節的障害につい て工藤ら ${ }^{19)}$ は, 平均 聴力 $60 \sim 79 \mathrm{~dB}$ 群, 80 99dB 群, $100 \mathrm{~dB}$ 以上群の 3 群の発語明瞭度は順に, $77.2 \%, 51.8$ \%，22.7\%であったと報告した。降矢 ${ }^{20)}$ の各種の音声障 害者（123名）について発語明瞭度の 社会的障害度を評 価した研究によると，発語明瞭度 $96 〜 71 \%$ を軽度の障害 とし，同70〜36\%を中度の障害，同35～0\%を重度の障 害と認められると報告されている．分節的障害につい て, 工藤 ${ }^{19)}$, 降矢 ${ }^{20)}$ の結果を参照し, 韻律的障害につい ての著者らの結果とをあわせて, 聴覚障害児の音声障害 と聴力との関係を述べると以下のとおりである.

(1)聴力 $80 \mathrm{~dB}$ 末満の症例に軽度の分節的障害と, 音声 強度の変動幅についての韻律的障害を認めた. (2)聴力 $80 \sim 99 \mathrm{~dB}$ の症例に, 中度の分節的障害と, 音声強度・ピ ッチ・速度についての $2 \sim 3$ 種の韻律的障害を認めた. (3)聴力 $100 \mathrm{~dB}$ 以上の症例に, 重度の分節的障害と, すべ ての韻律的側面の障害の悪化を認めたと概括できよう. 


\section{ま と め}

早期に（平均 2 歳 1 カ月）補聴器を装用させて, ホー ムトレーニングプログラムを施行した中・高度聴覚障害 児 (36例) の発話を音響的に分析した. ついで聴覚印象 によって音声障害の重症度を評価し, 聴カレベルの差異 が音声障害の種類と程度に及ぼす影響を検討した。 その 結果, (1)音声強度と強度の変動幅の増加を聴力 $70 \mathrm{~dB}$ 以 上の群に認めた. (2)発話速度の低下を聴力 $80 \mathrm{~dB}$ 以上の 群に認め, 聴力 $100 \mathrm{~dB}$ 以上の群では一層の低下を認め た. (3)ピッチの変動幅の減少は, 聴力 $90 \mathrm{~dB}$ 以上の群に 認めたが，ピッチの平均値は正常児と差がなかった.さ らに, (4)音声障害の予後の推定の際には, 聴力レベルが $90 \mathrm{~dB}$ 以上であるか否かについて検討することの有用性 が示唆された。

本結果は, 聴覚障害児の音声障害の評価の際や，系統 的な訓練を行ら際の資料として利用できる.

終稿にあたり, 聴覚印象評価にご協力下さいました小林はる よ氏, 福田友美子氏, 堀内美智子氏 (帝京大学), 佐川幸子氏 （東京医大霞浦分院）に哚謝いたします。

\section{文献}

1) Hudgins, C.V. : An investigation of the intelligibility of the speech of the deaf. Genetic Psychology Monograph, 25 : 292-392, 1942.

2) 切替一郎, 松崎 力, 船坂宗太郎 : 音声の動摇に関 する実験的研究. 日耳鼻, $68: 364-374,1964$.

3 ) Eguchi, S. : Clinical study of the deaf child, Acta Med. nagasaki, 9 : 135-171, 1965.

4) 鏡隆左衛門, 比企静雄 : 万丂, 難聴児の基本周波数 と強度の変化の特性. 日本音響学会誌, 31(3)：155$162,1975$.

5 ) 田中美郷, 他 : 聴覚障害児のリハビリテーション. 小児看護, 6(13)：1471-1480, 1983.

6) 田中美郷：われわれの臨床で訓練した難聴乳幼児の フォローアップーアンケートよりみた就学情況と言 語の問題. 音声言語医学, $24: 35-36,1983$.

7) Nickerson, R.S. : Characteristics of the speech of deaf persons. The Volta Review, $77: 342-362$, 1975.

8) Boone, D.R. : Modification of the voices of deaf children. The Volta Review, $68: 686-694,1966$.

9) Angelocci, A.A., Kopp, G.A. : The vowel formants of deaf and normal hearing 11-to 14-year old boys. J. Speech Hear. Dis., $29: 156-170,1964$.

10) Mectfessel, A. L. : A comparison between vocal characteristics of deaf and normal hearing individuals. Unpublished master's thesis, University of Kansas, 1965.

11) Ermovick, D.A. : A spectrographic analysis comparing connected speech of deaf subjects and hearing subjects. Unpublished master's thesis, university of Kansas, 1965.

12) Martony, J. : On the correction of falsetto voice pitch level for severely hard of hearing subjects, American Annals of the Deaf., $113: 195-202$, 1968.

13) Willemain, T.R., Lee, F.F. : Tactile pitch feedback for deaf speakers. The Volta Review., $73: 541-$ $554,1971$.

14) John, J. E. J., Howardth, J. N. : The effect of time distortions on the intelligibility of deaf children's speech, Language and Speech., $8: 127-134,1965$.

15) Colton, R.H. and Cooker, H.S. : Perceived nasality in the speech of the deaf. J. Speech Hear. Res., $11: 553-559,1968$.

16) Fletcher, S.G. and Daly, D.A. : Nasalance in utterances of hearing impaired speakers. J. Commun. Dis., $9: 63-73,1976$.

17) Tato, J.M. and Arcella, A.I. : cited by Wilson, D. K. : Voice problems of children. Williams \& Wilkins, 183-184, 1981.

18) Angelocci, A.A. : Some observations on the speech of the deaf. The Volta Review, $64: 403-405,1962$.

19）工藤多賀, 厷田栄子, 田中美郷 : 難聴児のフォロー アップ——難聴児の聴力程度と発語明膫度との関係 よりみて—Audiology Japan, 28(2):107-112, 1985.

20）降矢宜成：言語障害の語音発語明瞭度（語明度）に 関する研究. 日耳鼻, $61: 166-193,1947$.

別刷請求先 : $\mathbf{\boldsymbol { T }} 173$ 東京都板橋区加賀2-11-1 帝京大学医学部耳鼻咽喉科学教室 広田栄子 